Article

\title{
Novel Quaternary Ammonium Derivatives of 4-Pyrrolidino Pyridine: Synthesis, Structural, Thermal, and Antibacterial Studies
}

\author{
Rusi Rusew ${ }^{1, *}$, Vanya Kurteva ${ }^{2} \mathbb{C}$ and Boris Shivachev ${ }^{1}$ \\ 1 Institute of Mineralogy and Crystallography "Acad. Ivan Kostov", Bulgarian Academy of Sciences, \\ Acad. G. Bonchev str., bl. 107, 1113 Sofia, Bulgaria; bls@clmc.bas.bg \\ 2 Institute of Organic Chemistry with Centre of Phytochemistry, Bulgarian Academy of Sciences, \\ Acad. G. Bonchev str., bl. 9, 1113 Sofia, Bulgaria; vkurteva@orgchm.bas.bg \\ * Correspondence: r.rusev93@imc.bas.bg
}

Received: 31 March 2020; Accepted: 23 April 2020; Published: 25 April 2020

\begin{abstract}
Six novel quaternary ammonium derivatives of 4-pyrrolidino pyridine were prepared and isolated via a facile one-pot synthesis and a simple purification procedure. The purity and the molecular structure of the 4-pyrrolidino pyridine derivatives were confirmed with ${ }^{1} \mathrm{H}$ and ${ }^{13} \mathrm{C} \mathrm{NMR}$ spectroscopy and powder X-ray diffraction techniques. The crystal structures of the compounds were characterized by single crystal X-ray diffraction (SCXRD) and their thermal properties were studied by Differential Scanning Calorimetry (DSC) analyses. The antibacterial properties of the title compounds against five bacterial strains were evaluated using Kirby-Bauer disk diffusion susceptibility test. The compounds crystallize in the monoclinic or orthorhombic crystal systems (space groups: $P 2_{1} / c, P 2_{1} / n$, or $P 2_{1} 2_{1} 2_{1}$ ) and their crystal structures are stabilized by a combination of intra- and intermolecular halogen bonding interactions, short contacts and $\pi-\pi$ interactions. Above interactions, they contribute to the thermal stability and lack of phase transition effects up to $350{ }^{\circ} \mathrm{C}$. Two of the compounds possess antibacterial effect against E. coli or S. aureus bacterial strains-similar or better than the kanamycin reference.
\end{abstract}

Keywords: single crystal XRD; NMR; powder XRD; DSC; quaternary ammonium salts; antibacterial activity

\section{Introduction}

The rapidly increasing bacterial resistance against regularly used antibiotics and antimicrobial agents motivates the necessity for discovery of new antibacterial compounds. The quaternary ammonium salts (QAS) are promising candidates in this regard. They are heterocyclic compounds, composed of positive nitrogen "head" and lipophilic "tail". This structural peculiarity determines QAS's amphiphilic properties and contributes to their broad range of applications namely as cationic surfactants [1,2], phase-transfer catalysts [3,4], fabric softeners [5], ionic liquids [6,7], lithium battery binders $[8,9]$, etc. Compounds such as benzalkonium chloride, cetalkonium chloride, etc., are an integral part of different household, industrial, and clinical non-selective disinfectants because of their strong bacteriostatic and bactericidal effect. In general, the basic mechanisms of biological activity of antibiotics involve metabolic pathway inhibition, interference with the synthesis of essential nucleic acids and cell wall components or disruption of the bacterial membrane [10]. The last mechanism is considered to be the main feature of QAS's antibacterial action based on the electrostatic and/or hydrophobic interactions with the negatively charged cell membrane. Such interactions destabilize the intracellular matrix of the bacteria, leading to leakage of essential fluids and cell death [11]. On the other hand, principal microbial mechanisms of drug resistance are based on gene mutations and horizontal 
gene-transfer (HGT) [12,13]. The mutations, for instance, can increase the bacterial ability to produce antibiotic targeting enzymes, e.g., $\beta$-lactamases that reduce the concentration of the drug or may also intensify the over-expression of specific protein transporters ("efflux pumps") that can expel the antibacterial agent out of the cell [14-16]. The "efflux pumps", in particular, are one of the main reasons for reduced activity of quaternary ammonium salt based antibacterial drugs. Another reason is the structure of the bacterial membrane as QASs are less active against Gram-negative than Gram-positive bacteria due to the presence of additional outer lipid layer.

Several authors [17-19] point out, that in order to be effective antibacterial agents, the optimal length of the QAS's carbon linkers/chains should be around 12 to 16 carbon atoms. Thus, to exploit/enhance the biological properties and counteract the mechanisms of resistance, QASs are incorporated (encapsulated) in different types of materials and are subject to various studies. Kang et al. [20] work up cotton fibers with a mixture of QASs and silver particles that possess synergistic antimicrobial properties against P. aeruginosa. Liu et al. [21] prepared terpene based polyurethane coatings containing chemically bonded quaternary ammonium salts that exhibit significant antibacterial activity against $S$. aureus and E. coli. Several studies focus on chitosan-QAS antifungal properties against phytopathogenic fungal species [22-24]. The 4-pyrrolidino pyridine (4PP) moiety as a target of quaternization has been acknowledged in recent years. The 4PP quaternary ammonium derivatives are part of diverse scientific studies encompassing various applications as: potent acetyl- and butyrylcholinesterase inhibitors [25]; catalysts for alkene isomerization-hydroboration reactions [26]; asymmetric non-enzymatic catalysis of acyl-transfer reactions [27]; catalysts for 1,2- and 1,4-addition reactions [28] and even as part of different metal-organic complexes [29], etc.

In general, the quaternization process, pioneered by Menshutkin, is best described as $\mathrm{S}_{\mathrm{N}} 2$ reaction, where tertiary amine reacts with alkyl (aryl) substituted halide to form quaternary ammonium salt [30]. The role of the reaction media is important and polar aprotic solvents are favored because they contribute to the formation of solvate ions [31-33]. Different modifications of the reaction $[34,35]$ were made through the years in order to increase the yield, reactivity, and to facilitate the purification process. The antimicrobial activity research involving the 4-pyrrolidine pyridine fragment-in particular-is a continuation of our previous reported paper that hints the potential antimicrobial properties of such chemical species [36].

Herein, we report on a facile one-step synthesis of quaternary ammonium derivatives of 4-pyrrolidino pyridine, in which the long aliphatic "tail" is replaced by compact aryl-containing substituents, their solution, solid state characterization, thermal properties, and antimicrobial activity against Gram-positive and Gram-negative bacterial strains.

\section{Materials and Methods}

\subsection{Synthesis and Crystallization}

All starting reagents were purchased from AlfaAesar and were used without additional purification. The general one-step procedure for the synthesis (Scheme 1) of the quaternary ammonium compounds involved dissolution of the starting compounds in polar aprotic solvent (acetonitrile (ACN)) with constant stirring at temperature near the boiling point of the solvent. The reactions were performed in inert atmosphere (argon) because of the possible hydrolysis of the halogen compounds. Due to the excellent solubility of the starting reagents in the reaction media, the end of quaternization was marked with the formation of microcrystalline precipitate. In some cases, even large single crystals appeared directly from the acetonitrile solution after cooling down to room temperature $\left(22{ }^{\circ} \mathrm{C}\right)$. The purification procedure consisted of several washes with solvent and/or recrystallization from methanol or methanol/acetone. The purity and the molecular structure of the synthesized compounds was confirmed with ${ }^{1} \mathrm{H}$ and ${ }^{13} \mathrm{C}$ NMR spectroscopy and powder $\mathrm{X}$-ray diffraction techniques. 


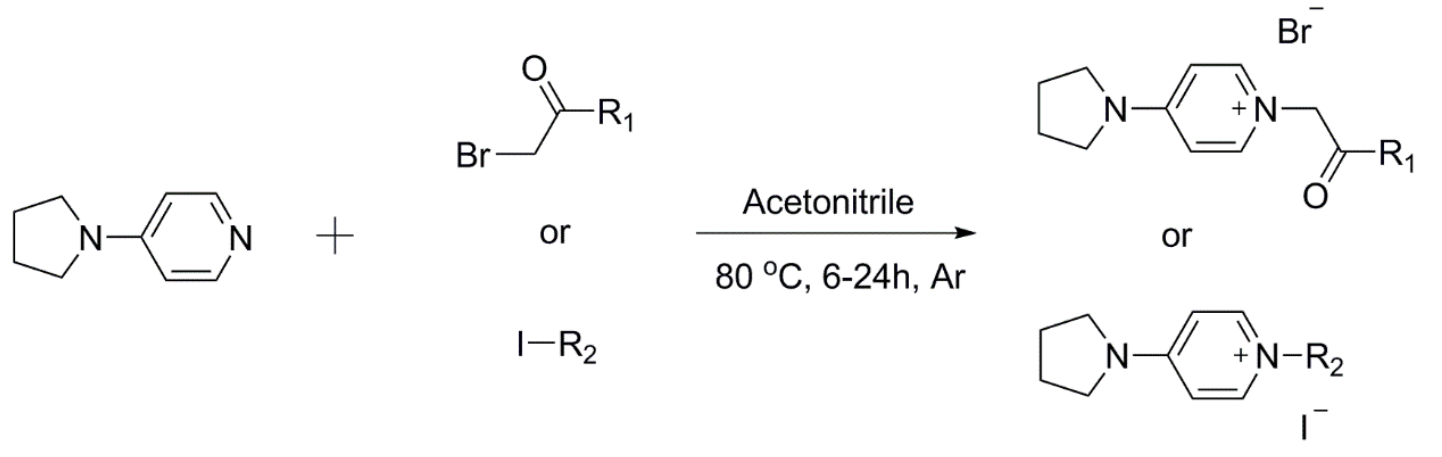

$R_{1}:$ 3- $\mathrm{NO}_{2} \mathrm{C}_{6} \mathrm{H}_{4}$ (1), 3,4-(O- $\left.\mathrm{CH}_{2} \mathrm{CH}_{2} \mathrm{CH}_{2}-\mathrm{O}\right)-\mathrm{C}_{6} \mathrm{H}_{3}$ (2), 2,4-(OMe) ${ }_{2} \mathrm{C}_{6} \mathrm{H}_{3}$ (3), $\mathrm{Ph}$ (4), $\mathrm{BiPh}$ (5) $R_{2}$ : Butyl (6)

Scheme 1. General scheme for the synthesis of quaternary ammonium derivatives of 4-pyrrolidino pyridine (1-6).

2.1.1. Synthesis of 1-(2-(3-Nitrophenyl)-2-Oxoethyl)-4-(Pyrrolidin-1-yl)Pyridin-1-Ium Bromide, Compound 1

4-pyrrolidino pyridine $(74 \mathrm{mg}, 0.5 \mathrm{mmol}$ ) and 2-bromo-1-(3-nitrophenyl) ethan-1-one (122 $\mathrm{mg}$, $0.5 \mathrm{mmol}$ ) were dissolved in $5 \mathrm{~mL}$ acetonitrile. Crystalline precipitate formed almost immediately after dissolution and was left stirring for $6 \mathrm{~h}$ at $80^{\circ} \mathrm{C}$. The product was filtered and washed with acetonitrile. Crystals were extracted for SCXRD. Compound 1: yield $=61 \%$, light brown needles (ACN); mp 262-264 ${ }^{\circ} \mathrm{C} . ;{ }^{1} \mathrm{H}$ NMR (DMSO-d $\left.6,600 \mathrm{MHz}\right) \delta 2.202\left(4 \mathrm{H}, m, \mathrm{CH}_{2}-3\right.$ and $\left.\mathrm{CH}_{2}-4 \mathrm{Pir}\right), 3.523$ $\left(4 \mathrm{H}, m, \mathrm{CH}_{2}-2\right.$ and $\left.\mathrm{CH}_{2}-5 \mathrm{Pir}\right), 3.893\left(3 \mathrm{H}, s, \mathrm{OCH}_{3}-4 \mathrm{Ar}\right), 4.014\left(3 \mathrm{H}, s, \mathrm{OCH}_{3}-2 \mathrm{Ar}\right), \delta 5.657(2 \mathrm{H}, s$, $\left.\mathrm{CH}_{2}-\mathrm{CO}\right), 6.715(1 \mathrm{H}, d d, J=8.9 \mathrm{~Hz}, 2.3 \mathrm{~Hz}, \mathrm{CH}-5 \mathrm{Ar}), 6.774(1 \mathrm{H}, d, J=2.3 \mathrm{~Hz}, \mathrm{CH}-3 \mathrm{Ar}), 6.931(2 \mathrm{H}, d, J$ $=7.7 \mathrm{~Hz}, \mathrm{CH}-3$ and $\mathrm{CH}-5 \mathrm{Pyr}), \delta 7.846(1 \mathrm{H}, d, J=8.9 \mathrm{~Hz}, \mathrm{CH}-6 \mathrm{Ar}), \delta 8.174(2 \mathrm{H}, d, J=7.7 \mathrm{~Hz}, \mathrm{CH}-2$ and CH-6 Pyr); ${ }^{13} \mathrm{C}$ NMR (DMSO-d $\left.6,151 \mathrm{MHz}\right) \delta 25.17\left(\mathrm{CH}_{2}-3\right.$ and $\left.\mathrm{CH}_{2}-4 \mathrm{Pir}\right), 48.69\left(\mathrm{CH}_{2}-2\right.$ and $\mathrm{CH}_{2}-5$ Pir), $56.29\left(\mathrm{OCH}_{3}-4 \mathrm{Ar}\right), 56.71\left(\mathrm{OCH}_{3}-2 \mathrm{Ar}\right), 66.41\left(\mathrm{CH}_{2}-\mathrm{CO}\right), 98.79(\mathrm{CH}-3 \mathrm{Ar}), 107.48(\mathrm{CH}-5 \mathrm{Ar}), 108.06$ (CH-3 and $\mathrm{CH}-5 \mathrm{Pyr}), 116.85$ ( $\left.\mathrm{C}_{\mathrm{q}}-1 \mathrm{Ar}\right), 132.73(\mathrm{CH}-6 \mathrm{Ar}), 143.66(\mathrm{CH}-2$ and $\mathrm{CH}-6 \mathrm{Pyr}), 153.45\left(\mathrm{C}_{\mathrm{q}}-4\right.$ Pyr), $162.39\left(\mathrm{C}_{\mathrm{q}}-2 \mathrm{Ar}\right), 166.05\left(\mathrm{C}_{\mathrm{q}}-4 \mathrm{Ar}\right), 190.35(\mathrm{C}=\mathrm{O})$.

\subsubsection{Synthesis of}

1-(2-(3,4-Dihydro-2h-Benzo[B][1,4]Dioxepin-7-Yl)-2-Oxoethyl)-4-(Pyrrolidin-1-Yl)Pyridin-1-Ium Bromide, Compound 2

4-pyrrolidino pyridine (74 $\mathrm{mg}, \quad 0.5 \quad \mathrm{mmol}) \quad$ and 2-bromo-1-(3,4-dihydro-2H-benzo[b][1,4]dioxepin-7-yl)ethan-1-one (136 mg, $0.5 \mathrm{mmol}$ ) were dissolved in $5 \mathrm{~mL}$ acetonitrile and the solution was stirred for $24 \mathrm{~h}$ at $80^{\circ} \mathrm{C}$. After that the clear reaction mixture was left to cool down to $20^{\circ} \mathrm{C}$ and after 1 to $2 \mathrm{~h}$, colorless crystals started to form. Single crystals were extracted for SCXRD and the rest were filtered and washed with acetonitrile. Compound 2: yield 71\%, colorless blocks (ACN); mp 204-207 ${ }^{\circ} \mathrm{C} ;{ }^{1} \mathrm{H}$ NMR (DMSO-d $\left.6,600 \mathrm{MHz}\right) \delta 2.026(4 \mathrm{H}, m$, $\mathrm{CH}_{2}-3$ and $\left.\mathrm{CH}_{2}-4 \mathrm{Pir}\right), 2.188\left(2 \mathrm{H}, m, \mathrm{C}-\mathrm{CH}_{2}-\mathrm{C} \mathrm{Ar}\right), 3.529\left(4 \mathrm{H}, m, \mathrm{CH}_{2}-2\right.$ and $\left.\mathrm{CH}_{2}-5 \mathrm{Pir}\right), 4.227\left(2 \mathrm{H}, m, \frac{1}{2}\right.$ $\left.\mathrm{CH}_{2}-\mathrm{O} \mathrm{Ar}\right), 4.290\left(2 \mathrm{H}, m, \frac{1}{2} \mathrm{CH}_{2}-\mathrm{O} \mathrm{Ar}\right), 5.890\left(2 \mathrm{H}, s, \mathrm{CH}_{2}-\mathrm{CO}\right), 6.961(2 \mathrm{H}, d, J=7.7 \mathrm{~Hz}, \mathrm{CH}-3$ and CH-5 Pyr), $7.159(1 \mathrm{H}, d, J=8.3 \mathrm{~Hz}, \mathrm{CH}-5 \mathrm{Ar}), 7.607(1 \mathrm{H}, d, J=2.2 \mathrm{~Hz}, \mathrm{CH}-2 \mathrm{Ar}), 7.631(1 \mathrm{H}, d d, J=8.3 \mathrm{~Hz}$, $2.2 \mathrm{~Hz}, \mathrm{CH}-6 \mathrm{Ar}), 8.144\left(2 \mathrm{H}, d, J=7.7 \mathrm{~Hz}, \mathrm{CH}-2\right.$ and CH-6 Pyr); ${ }^{13} \mathrm{C}$ NMR (DMSO-d $\left.6,151 \mathrm{MHz}\right) \delta$ $25.06\left(\mathrm{CH}_{2}-3\right.$ and $\left.\mathrm{CH}_{2}-4 \mathrm{Pir}\right), 30.94\left(\mathrm{C}-\mathrm{CH}_{2}-\mathrm{C} \mathrm{Ar}\right), 48.76\left(\mathrm{CH}_{2}-2\right.$ and $\left.\mathrm{CH}_{2}-5 \mathrm{Pir}\right), 62.57\left(\mathrm{CH}_{2}-\mathrm{CO}\right)$, 70.89 ( $\left.\mathrm{CH}_{2}-\mathrm{O} \mathrm{Ar}\right), 108.31$ (CH-3 and $\left.\mathrm{CH}-5 \mathrm{Pyr}\right), 122.09$ (CH-2 Ar), 122.31 (CH-5 Ar), 124.28 (CH6 Ar), $129.39\left(\mathrm{C}_{\mathrm{q}}-1 \mathrm{Ar}\right), 143.56(\mathrm{CH}-2$ and $\mathrm{CH}-6 \mathrm{Pyr}), 150.84\left(\mathrm{C}_{\mathrm{q}}-3 \mathrm{Ar}\right), 153.47\left(\mathrm{C}_{\mathrm{q}}-4 \mathrm{Pyr}\right), 156.34\left(\mathrm{C}_{\mathrm{q}}-4 \mathrm{Ar}\right)$, $191.20(\mathrm{C}=\mathrm{O})$. 
2.1.3. Synthesis of 1-(2-(2,4-Dimethoxyphenyl)-2-Oxoethyl)-4-(Pyrrolidin-1-yl)Pyridin-1-Ium Bromide, Compound 3

4-pyrrolidino pyridine (74 $\mathrm{mg}, 0.5 \mathrm{mmol}$ ) and 2-bromo-1-(2,4-dimethoxyphenyl)ethan-1-one $\left(130 \mathrm{mg}, 0.5 \mathrm{mmol}\right.$ ) were dissolved in $5 \mathrm{~mL}$ acetonitrile and the solution was stirred for $24 \mathrm{~h}$ at $80{ }^{\circ} \mathrm{C}$ and remained colorless. The reaction mixture was left to cool down and slowly evaporate at $25^{\circ} \mathrm{C}$, and after $72 \mathrm{~h}$ crystals started to form. Single crystals were extracted for SCXRD. Compound 3: colorless plates (ACN); yield: 74\%; mp 218-224 ${ }^{\circ} \mathrm{C} ;{ }^{1} \mathrm{H}$ NMR (DMSO-d $\left.6,600 \mathrm{MHz}\right) \delta 2.202(4 \mathrm{H}, m$, $\mathrm{CH}_{2}-3$ and $\left.\mathrm{CH}_{2}-4 \mathrm{Pir}\right), 3.523\left(4 \mathrm{H}, m, \mathrm{CH}_{2}-2\right.$ and $\left.\mathrm{CH}_{2}-5 \mathrm{Pir}\right), 3.893\left(3 \mathrm{H}, s, \mathrm{OCH}_{3}-4 \mathrm{Ar}\right), 4.014(3 \mathrm{H}, \mathrm{s}$, $\left.\mathrm{OCH}_{3}-2 \mathrm{Ar}\right), 5.657\left(2 \mathrm{H}, s, \mathrm{CH}_{2}-\mathrm{CO}\right), 6.715(1 \mathrm{H}, d d, J=8.9 \mathrm{~Hz}, 2.3 \mathrm{~Hz}, \mathrm{CH}-5 \mathrm{Ar}), 6.774(1 \mathrm{H}, d, J=2.3 \mathrm{~Hz}$, CH-3 Ar), $6.931(2 \mathrm{H}, d, J=7.7 \mathrm{~Hz}, \mathrm{CH}-3$ and CH-5 Pyr $), 7.846(1 \mathrm{H}, d, J=8.9 \mathrm{~Hz}, \mathrm{CH}-6 \mathrm{Ar}), 8.174(2 \mathrm{H}$, $d, J=7.7 \mathrm{~Hz}, \mathrm{CH}-2$ and CH-6 Pyr); ${ }^{13} \mathrm{C}$ NMR (DMSO-d $\left.\mathrm{d}_{6}, 151 \mathrm{MHz}\right) \delta 25.17\left(\mathrm{CH}_{2}-3\right.$ and $\left.\mathrm{CH}_{2}-4 \mathrm{Pir}\right)$, $48.69\left(\mathrm{CH}_{2}-2\right.$ and $\left.\mathrm{CH}_{2}-5 \mathrm{Pir}\right), 56.29\left(\mathrm{OCH}_{3}-4 \mathrm{Ar}\right), 56.71\left(\mathrm{OCH}_{3}-2 \mathrm{Ar}\right), 66.41\left(\mathrm{CH}_{2}-\mathrm{CO}\right), 98.79(\mathrm{CH}-3 \mathrm{Ar})$, 107.48 (CH-5 Ar), 108.06 (CH-3 and CH-5 Pyr), 116.85 (C $\left.\mathrm{C}_{\mathrm{q}}-1 \mathrm{Ar}\right), 132.73$ (CH-6 Ar), 143.66 (CH-2 and CH-6 Pyr), 153.45 (C $\left.\mathrm{q}_{\mathrm{q}}-4 \mathrm{Pyr}\right), 162.39$ ( $\left.\mathrm{C}_{\mathrm{q}}-2 \mathrm{Ar}\right), 166.05$ (C $\left.\mathrm{q}^{-4} \mathrm{Ar}\right), 190.35(\mathrm{C}=\mathrm{O})$.

2.1.4. Synthesis of 1-(2-Oxo-2-Phenylethyl)-4-(Pyrrolidin-1-yl) Pyridin-1-Ium Bromide, Compound 4

4-pyrrolidino pyridine (74 mg, $0.5 \mathrm{mmol}$ ) and 2-bromacetophenone (100 mg, $0.5 \mathrm{mmol}$ ) were dissolved in $5 \mathrm{~mL}$ ACN. After constant stirring at $80^{\circ} \mathrm{C}$ in inert (argon) atmosphere for $24 \mathrm{~h}$, the solution turned orange and was left to cool down and slowly crystalize at room temperature. Large orange crystals, formed within a week, were filtered and washed with acetonitrile. Compound 4: orange blocks (ACN) yield: 70\%; mp 266-271 ${ }^{\circ} \mathrm{C} ;{ }^{1} \mathrm{H}$ NMR (DMSO-d $\left.{ }_{6}, 600 \mathrm{MHz}\right) \delta 2.031\left(4 \mathrm{H}, m, \mathrm{CH}_{2}-3\right.$ and $\left.\mathrm{CH}_{2}-4 \mathrm{Pir}\right), 3.539\left(4 \mathrm{H}, m, \mathrm{CH}_{2}-2\right.$ and $\left.\mathrm{CH}_{2}-5 \mathrm{Pir}\right), 5.998\left(2 \mathrm{H}, \mathrm{s}, \mathrm{CH}_{2}-\mathrm{CO}\right), 6.982(2 \mathrm{H}, d, J=7.7 \mathrm{~Hz}$, CH-3 and CH-5 Pyr), $7.640(2 \mathrm{H}, d, J=7.7 \mathrm{~Hz}, \mathrm{CH}-3$ and $\mathrm{CH}-5 \mathrm{Ph}), 7.766(1 \mathrm{H}, t t, J=7.4 \mathrm{~Hz}, 2.1 \mathrm{~Hz}$, CH-4 Ph), $8.038(2 \mathrm{H}, d, J=7.5 \mathrm{~Hz}, \mathrm{CH}-2$ and CH-6 Ph), $8.190(2 \mathrm{H}, d, J=7.7 \mathrm{~Hz}, \mathrm{CH}-2$ and CH-6 Pyr); ${ }^{13} \mathrm{C}$ NMR (DMSO-d $\left.\mathrm{d}_{6}, 151 \mathrm{MHz}\right) \delta 25.18\left(\mathrm{CH}_{2}-3\right.$ and $\left.\mathrm{CH}_{2}-4 \mathrm{Pir}\right), 48.85\left(\mathrm{CH}_{2}-2\right.$ and $\left.\mathrm{CH}_{2}-5 \mathrm{Pir}\right), 62.93$ ( $\left.\mathrm{CH}_{2}-\mathrm{CO}\right), 108.47$ (CH-3 and $\left.\mathrm{CH}-5 \mathrm{Pyr}\right), 128.56$ (CH-2 and $\left.\mathrm{CH}-6 \mathrm{Ph}\right), 129.55(\mathrm{CH}-3$ and $\mathrm{CH}-5 \mathrm{Ph}), 134.31$ ( $\left.\mathrm{C}_{\mathrm{q}}-1 \mathrm{Ph}\right), 134.92(\mathrm{CH}-4 \mathrm{Ph}), 143.69$ (CH-2 and CH-6 Pyr), $153.62\left(\mathrm{C}_{\mathrm{q}}-4 \mathrm{Pyr}\right), 192.90(\mathrm{C}=\mathrm{O})$.

2.1.5. Synthesis of 1-(2-([1,1'-Biphenyl]-4-yl)-2-Oxoethyl)-4-(Pyrrolidin-1-yl) Pyridin-1-Ium Bromide, Compound 5

4-pyrrolidino pyridine (74mg, $0.5 \mathrm{mmol})$ and 1-([1,1'-biphenyl]-4-yl)-2-bromoethan-1-one (138 mg, $0.5 \mathrm{mmol}$ ) were dissolved in $5 \mathrm{~mL}$ acetonitrile. The solution was stirred for $24 \mathrm{~h}$ at $80^{\circ} \mathrm{C}$ resulting in a pinkish white precipitate that was filtered and washed with acetonitrile. Orange single crystals suitable for SCXRD were obtained after recrystallization from methanol. Compound 5: orange blocks (methanol); yield 69\%; mp 288-291 ${ }^{\circ} \mathrm{C} ;{ }^{1} \mathrm{H}$ NMR (DMSO-d $\left.\mathrm{d}_{6}, 600 \mathrm{MHz}\right) \delta 2.236\left(4 \mathrm{H}, m, \mathrm{CH}_{2}-3\right.$ and $\mathrm{CH}_{2}-4$ Pir), $3.545\left(4 \mathrm{H}, m, \mathrm{CH}_{2}-2\right.$ and $\left.\mathrm{CH}_{2}-5 \mathrm{Pir}\right), 6.015\left(2 \mathrm{H}, s, \mathrm{CH}_{2}-\mathrm{CO}\right), 6.992(2 \mathrm{H}, d, J=7.7 \mathrm{~Hz}, \mathrm{CH}-3$ and CH-5 Pyr), $7.468\left(1 \mathrm{H}, t t, J=7.4 \mathrm{~Hz}, 1.2 \mathrm{~Hz}, \mathrm{CH}-4^{\prime} \mathrm{BiPh}\right), 7.540\left(2 \mathrm{H}, d d, J=8.0 \mathrm{~Hz}, 7.4 \mathrm{~Hz}, \mathrm{CH}-3^{\prime}\right.$ and CH-5' BiPh), $7.810\left(2 \mathrm{H}, d d, J=8.1 \mathrm{~Hz}, 1.4 \mathrm{~Hz}, \mathrm{CH}-2^{\prime}\right.$ and $\left.\mathrm{CH}-6^{\prime} \mathrm{BiPh}\right), 7.962(2 \mathrm{H}, \mathrm{dd}, J=8.6 \mathrm{~Hz}, 1.9 \mathrm{~Hz}$, CH-3 and CH-5 BiPh), $8.118(2 \mathrm{H}, \mathrm{dd}, J=8.1 \mathrm{~Hz}, 1.4 \mathrm{~Hz}, \mathrm{CH}-2$ and $\mathrm{CH}-6 \mathrm{BiPh}), 8.203(2 \mathrm{H}, \mathrm{d}, J=7.6 \mathrm{~Hz}$, $\mathrm{CH}-2$ and $\mathrm{CH}-6 \mathrm{Pyr}) ;{ }^{13} \mathrm{C}$ NMR (DMSO-d $\left.6,151 \mathrm{MHz}\right) \delta 25.08\left(\mathrm{CH}_{2}-3\right.$ and $\left.\mathrm{CH}_{2}-4 \mathrm{Pir}\right), 48.81\left(\mathrm{CH}_{2}-2\right.$ and $\left.\mathrm{CH}_{2}-5 \mathrm{Pir}\right), 62.79$ ( $\left.\mathrm{CH}_{2}-\mathrm{CO}\right), 108.34(\mathrm{CH}-3$ and $\mathrm{CH}-5 \mathrm{Pyr}), 127.48$ (CH-3 and $\left.\mathrm{CH}-5 \mathrm{BiPh}\right), 127.49$ (CH-2' and $\left.\mathrm{CH}-6^{\prime} \mathrm{BiPh}\right), 129.18$ (CH-4' $\left.\mathrm{BiPh}\right), 129.24$ (CH-2 and $\left.\mathrm{CH}-6 \mathrm{BiPh}\right), 129.59$ (CH-3' and $\left.\mathrm{CH}-5^{\prime} \mathrm{BiPh}\right)$, $133.02\left(\mathrm{C}_{\mathrm{q}}-1 \mathrm{BiPh}\right), 138.89\left(\mathrm{C}_{\mathrm{q}^{-1}}{ }^{\prime} \mathrm{BiPh}\right), 143.56(\mathrm{CH}-2$ and $\mathrm{CH}-6 \mathrm{Pyr}), 145.97\left(\mathrm{C}_{\mathrm{q}}-4 \mathrm{BiPh}\right), 153.5362\left(\mathrm{C}_{\mathrm{q}^{-}}\right.$ Pyr), $192.37(\mathrm{C}=\mathrm{O})$.

\subsubsection{Synthesis of 1-Butyl-4-(Pyrrolidin-1-yl) Pyridin-1-Ium Iodide, Compound 6}

4-pyrrolidino pyridine $(74 \mathrm{mg}, 0.5 \mathrm{mmol})$ and butyl iodide $(92 \mathrm{mg}, 57 \mathrm{ul}, 0.5 \mathrm{mmol})$ were mixed in $5 \mathrm{~mL}$ ACN. The reaction was performed with constant stirring at temperature near the boiling point of the acetonitrile and in inert (argon) atmosphere for $24 \mathrm{~h}$. The solution was vacuum evaporated 
and the precipitate recrystallized from methanol/acetone solution resulting in light yellow crystals. Compound 6: light yellow blocks (methanol/acetone); yield: 65\%; mp 150-152 ${ }^{\circ} \mathrm{C}^{1}{ }^{1} \mathrm{H} \mathrm{NMR}\left(\mathrm{DMSO}_{\mathrm{d}}\right.$, $600 \mathrm{MHz}) \delta 0.871\left(3 \mathrm{H}, t, J=7.4 \mathrm{~Hz}, \mathrm{CH}_{3} \mathrm{Bu}\right), 1.211\left(2 \mathrm{H}, m, \mathrm{CH}_{2}-3 \mathrm{Bu}\right), 1.172\left(2 \mathrm{H}, m, \mathrm{CH}_{2}-2 \mathrm{Bu}\right)$, $1.982\left(4 \mathrm{H}, m, \mathrm{CH}_{2}-3\right.$ and $\left.\mathrm{CH}_{2}-4 \mathrm{Pir}\right), 3.469\left(4 \mathrm{H}, m, \mathrm{CH}_{2}-2\right.$ and $\left.\mathrm{CH}_{2}-5 \mathrm{Pir}\right), 4.143\left(2 \mathrm{H}, m, \mathrm{CH}_{2}-1 \mathrm{Bu}\right)$, $6.873(2 \mathrm{H}, d d, J=7.7 \mathrm{~Hz}, 1.8 \mathrm{~Hz}, \mathrm{CH}-3$ and CH-5 Pyr $), 8.284(2 \mathrm{H}, d d, J=7.7 \mathrm{~Hz}, 1.8 \mathrm{~Hz}, \mathrm{CH}-2$ and CH-6 Pyr); ${ }^{13} \mathrm{C}$ NMR (DMSO-d 6 , 151MHz) $\delta 13.86\left(\mathrm{CH}_{3} \mathrm{Bu}\right), 19.14\left(\mathrm{CH}_{2}-3 \mathrm{Bu}\right), 25.18\left(\mathrm{CH}_{2}-3\right.$ and $\left.\mathrm{CH}_{2}-4 \mathrm{Pir}\right)$, $32.82\left(\mathrm{CH}_{2}-2 \mathrm{Bu}\right), 48.76\left(\mathrm{CH}_{2}-2\right.$ and $\left.\mathrm{CH}_{2}-5 \mathrm{Pir}\right), 56.93\left(\mathrm{CH}_{2}-1 \mathrm{Bu}\right), 108.77(\mathrm{CH}-3$ and $\mathrm{CH}-5 \mathrm{Pyr}), 142.45$ (CH-2 and $\mathrm{CH}-6 \mathrm{Pyr}), 153.34\left(\mathrm{C}_{\mathrm{q}}-4 \mathrm{Pyr}\right)$.

\subsection{Characterization Methods}

\subsubsection{Single Crystal X-ray Diffraction (SCXRD)}

Single crystals of the quaternary ammonium compounds with suitable size and diffracting quality were mounted on glass capillaries or nylon loops. The diffraction peak intensities and coordinates were collected on Agilent SupernovaDual diffractometer equipped with Atlas CCD detector using micro-focus MoK $\alpha$ radiation $(\lambda=0.71073 \AA$ ). Data were processed with CrysAlisPro software [37]. The structures were solved with direct methods and refined by the full-matrix least-squares method on $F^{2}$ with ShelxS and ShelxL programs [38]. All non-hydrogen atoms were located successfully from Fourier map and were refined anisotropically. Hydrogen atoms were placed on calculated positions riding on the parent atom $\left(\mathrm{U}_{\text {eq }}=1.2\right.$ for $\mathrm{C}-\mathrm{H}_{\text {aromatic }}=0.93 \AA$ and $\left.\mathrm{C}-\mathrm{H}_{\text {methylenic }}=0.97 \AA\right)$. Complete crystallographic data for the structures of compounds 1-6 reported in this paper have been deposited in the CIF format with the Cambridge Crystallographic Data Center as 1992663, 1992664, 1992661, 1992662, 1992660, and 1992665. These data can be obtained free of charge via http://www.ccdc.cam.ac.uk/conts/retrieving.html (or from the CCDC, 12 Union Road, Cambridge CB2 1EZ, UK; Fax: +441223336033; E-mail: deposit@ccdc.cam.ac.uk).

\subsubsection{Powder X-ray Diffraction (PXRD)}

Powder samples of the synthesized quaternary ammonium compounds were analyzed on Empyrean Powder X-ray diffractometer (Malvern Panalytical, Netherlands) in the range $2^{\circ}-50^{\circ} 2 \theta$ using Cu radiation $(\lambda=1.5406 \AA)$ and PIXcel3D detector. The diffraction patterns of the precipitates were compared with those generated from the SCXRD experiment to confirm the presence or absence of additional phases.

\subsubsection{Nuclear Magnetic Resonance (NMR) Spectroscopy}

The NMR spectra were recorded on a Bruker Avance II+ 600 spectrometer (Rheinstetten, Germany), ${ }^{1} \mathrm{H}$ at $600 \mathrm{MHz}$ and ${ }^{13} \mathrm{C}$ at $151 \mathrm{MHz}$, in DMSO- $\mathrm{d}_{6}$; the chemical shifts were quoted in ppm in $\delta$-values against the solvent peak and the coupling constants were calculated in $\mathrm{Hz}$. The spectra were processed with Topspin 2.1 program. For simplicity, pyridyl ring nuclei are depicted as Pyr, pyrrolidine unit as $\mathrm{Pir}$, and $\mathrm{N}^{+}$-substituents, respectively, as $\mathrm{Bu}$ (butyl), $\mathrm{Ph}$ (phenyl), $\mathrm{BiPh}$ (biphenyl), and $\mathrm{Ar}\left(3-\mathrm{NO}_{2} \mathrm{C}_{6} \mathrm{H}_{4}\right.$, 2,4-(OMe $)_{2} \mathrm{C}_{6} \mathrm{H}_{3}$ and 3,4-(O- $\left.\left.-\mathrm{CH}_{2} \mathrm{CH}_{2} \mathrm{CH}_{2}-\mathrm{O}\right)-\mathrm{C}_{6} \mathrm{H}_{3}\right)$. The carbon resonances of compounds 1-3 were extracted from $2 \mathrm{D}$ heterocorrelations HSQC and $\mathrm{HMBC}$.

\subsubsection{Differential Scanning Calorimetry (DSC)}

DSC analyzes were performed on Discovery DSC 250 (TA instruments). Samples weighing between 1 and $5 \mathrm{mg}$ were heated in aluminum pans from 20 to $350{ }^{\circ} \mathrm{C}\left(10{ }^{\circ} \mathrm{C} \cdot \mathrm{min}^{-1}\right)$ in argon (flow rate $10 \mathrm{~mL} \cdot \mathrm{min}^{-1}$ ). Melting points of the synthesized compounds were determined from the DSC experiments. 


\subsubsection{Disk-Diffusion Method (Kirby-Bauer Test)}

The susceptibility of the selected bacterial strains (Klebsiella pneumoniae subspecies ozaenae- (CNCTC 1/35 SZU), Pseudomonas aeruginosa (CNCTC Ps 41/65), Escherichia coli, Staphylococcus aureus-ATCC 6538 and Bacillus subtilis) against the synthesized quaternary ammonium compounds (1-6) were evaluated using the Kirby-Bauer test. Solutions of compounds 1-6 with concentration of $1 \mathrm{mg} / \mathrm{mL}$ in $2 \%$ DMSO were prepared. A volume, corresponding to $30 \mu \mathrm{g}$ of the tested compound was pipetted on sterile cellulose discs ( $6 \mathrm{~mm}$ in diameter). Warm $\left(50-55^{\circ} \mathrm{C}, \sim 25 \mathrm{~mL}\right.$ ) Mueller-Hinton agar (containing 1.5\% agar) medium was poured into 90 or $60 \mathrm{~mm}$ sterile Petri dishes. The prepared dishes were left to cool down and solidify for $6 \mathrm{~h}$. Bacterial suspensions in liquid growth medium (Lysogeny broth) with concentrations of $\sim 1.10^{7} \mathrm{cfu} \cdot \mathrm{mL}^{-1}$ (0.5 McFarland standard) were prepared. Small amounts $(\sim 0.1-0.2 \mathrm{~mL})$ of each bacterial suspension were pipetted on the solid agar dishes and gently spread across the surface using cell spreader. After what dried cellulose discs with studied compounds were placed on the surface of the solidified growth medium. The plates were then incubated at $37^{\circ} \mathrm{C}$ for 12 to $18 \mathrm{~h}$. The diameters of the areas around the discs in which no growth is observed were measured.

\section{Results and Discussion}

\subsection{Single Crystal XRD Studies}

As part of the facile purification procedure, colorless (2 and 3), light brown (1) and yellow to orange $(4,5$, and 6$)$ single crystals of the title compounds were obtained by slow evaporation method from hot methanol, acetonitrile or methanol-acetone solutions. The 4-pyrrolidino pyridine derivatives crystallize as bromine (1-5) or iodine (6) salts in the monoclinic (S.G. $P 2_{1} / c-1,2$ and $P 2_{1} / n-3,5$, and 6) or in the orthorhombic (S.G. $\left.P 2{ }_{1} 2_{1} 2_{1}, 4\right)$ crystal system, bearing one molecule in the asymmetric unit (ASU) and four molecules in the unit cell (Table S1). ORTEP [39] view of the molecules present in the ASU of compounds 1-6 with appropriate labeling scheme are shown on Figure 1. The values for selected bond lengths and angles determined from the SCXRD experiment (Table S2) are in agreement with those of other similar structures in the Cambridge structural database (CCDC, ref. codes: QAWPAG, AGEPOR, EKOJOF [40-42]).

The reported quaternary ammonium bromine salts $\mathbf{1}-\mathbf{5}$ can be described as build-up of two fragments-4-pyrrolidino pyridine and different aromatic substituents $\left(3-\mathrm{NO}_{2} \mathrm{C}_{6} \mathrm{H}_{4}\right.$ for $\mathbf{1}$, 3,4-(O- $\left.\mathrm{CH}_{2} \mathrm{CH}_{2} \mathrm{CH}_{2}-\mathrm{O}\right)-\mathrm{C}_{6} \mathrm{H}_{3}$ for 2, 2,4-(OMe ${ }_{2} \mathrm{C}_{6} \mathrm{H}_{3}$ for 3, phenyl for 4 and biphenyl for 5) - connected via 2-oxoethyl $\left(-\mathrm{CH}_{2}-\mathrm{C}=\mathrm{O}\right)$ bridge. On the other hand, compound 6 is a 4-pyrrolidino pyridine iodine salt where the aromatic tertiary nitrogen atom is quaternized by an aliphatic butyl substituent. The flexibility of the carbon atoms in the pyrrolidine heterocycle ("half-chair" conformation), leads to a high probability of positional disorder. Indeed, atoms C2 and C3 in the pyrrolidine ring of 1, 2, and $\mathbf{5}$ are disordered over two position (as shown on Figure 1a,b,e) with occupancy ratio between the different disordered parts: $60 \% / 40 \%$ for $1,58 \% / 42 \%$ for 2 , and $70 \% / 30 \%$ for 5 . Other than that, the two cyclic fragments constructing the QAS molecule are relatively planar with RMSD of the 4-pyrrolidino pyridine fragment for all structures varying between $0.073 \AA$ (in 5) and $0.143 \AA$ (in 6) and those of the aromatic substituents between $0.005 \AA$ (for phenyl ring in 4) and $0.326 \AA$ (for 3,4- $\left(\mathrm{O}-\mathrm{CH}_{2} \mathrm{CH}_{2} \mathrm{CH}_{2}-\mathrm{O}\right)-\mathrm{C}_{6} \mathrm{H}_{3}$ substituent in 2). The angle between the mean planes of the two fragments varies significantly with values between $22.09^{\circ}$ (for 5) and $91.00^{\circ}$ (for 2 ). The pronounced variations in the above mentioned angles along with the occurrence of single bond between C11 and C12 indicate a good rotational flexibility of the aromatic substituents that can be a crucial part in the antimicrobial activity mechanism. A close inspection of the molecular features of compounds 1-6, reveals the lack of strong proton donating groups (such as $\mathrm{NH}_{2}$ or $\mathrm{OH}$ ), required for hydrogen bonding interactions. On the other hand, strong proton accepting groups as $\mathrm{C}=\mathrm{O}$ (for 1-5) and $\mathrm{NO}_{2}$ (for $\mathbf{1}$ ) or moderately strong ones as $\mathrm{C}-\mathrm{O}-\mathrm{C}$ in compound $\mathbf{2}$ and $-\mathrm{O}-\mathrm{CH}_{3}$ in $\mathbf{3}$ are present. Therefore, the formation of typical hydrogen bonding interactions is impossible. Thus, the only possibilities for intra- or intermolecular interactions stabilizing the crystal structures depends on the presence of 
halogen (bromine or iodine) anions, e.g., formation of "strong" halogen bonds or weak C-H...O and $\pi-\pi$ interactions involving $\mathrm{CH}_{2}$ or $\mathrm{CH}$ groups from the aliphatic or aromatic systems. Indeed, the three dimensional packing of the molecules in the crystal structures of 1-5 discloses a network of strong ( $H \cdots X$ distance of 2.69-3.28 $\AA$ ) halogen bonding interactions and short contacts of $\mathrm{C}-\mathrm{H}_{\text {methylenic }} \cdots \mathrm{X}$ and $\mathrm{C}-\mathrm{H}_{\text {aromatic }} \cdots \mathrm{X}$ type $\left(\mathrm{X}=\mathrm{Br}^{-}\right.$and $\mathrm{I}^{-}$, Table S3). Along with the above mentioned $\mathrm{H}^{\prime \cdots} \mathrm{X}$ interactions, the more common $\mathrm{C}-\mathrm{H} \cdots \mathrm{O}$ interactions involving $\mathrm{C}-\mathrm{H}_{\text {methylenic }}$ and $\mathrm{C}-\mathrm{H}_{\text {aromatic }}$ hydrogen atoms and $\mathrm{C}-\mathrm{O}-\mathrm{C}$ and $\mathrm{C}=\mathrm{O}$ functional groups in 2 and 3 forms $\mathrm{R}_{2}{ }^{2}(8)$ and $\mathrm{R}_{2}{ }^{2}(10)$ motifs $[43,44]$ respectively (Figure 2a,b). Compound 6, bearing only 4-pyrrolidino pyridine and butyl fragments, stabilize its crystal structure through a chain of $\mathrm{C}-\mathrm{H}_{\text {metylenic }} \cdots \mathrm{I}$ and $\mathrm{C}-\mathrm{H}_{\text {aromatic }} \cdots \mathrm{I}$ intermolecular interactions forming $\mathrm{C}_{2}{ }^{1}(6)$ motifs (Figure 2c) [43,44]. In addition, compounds $\mathbf{2}$ and $\mathbf{3}$ contain acetonitrile or water molecules (e.g., crystal solvates or hydrates), occupying the cavities between the QASs molecules. The water molecule is involved in hydrogen bonding interaction with $\mathrm{Br}$ and thus further stabilize the crystal structure of $\mathbf{3}$. The solvent acetonitrile in $\mathbf{2}$ is also involved in the crystal structure stabilization through $\mathrm{C}-\mathrm{H} \cdots \mathrm{X}$ interactions with the $\mathrm{Br}$ anion (Figure $2 \mathrm{a}, \mathrm{b}$ and Table S3). Stacking $\pi-\pi$ interactions can be found on three of the reported QASs-1, 3, and $\mathbf{5}$. Compound $\mathbf{1}$ has two nearly parallel stacked nitrobenzene rings (the angle between the mean planes of the benzene rings is $0^{\circ}$ ). The 2,4-dimetoxy benzene and pyridine ring for 3 and the phenyl ring (C18-C19-C20-C21-C22-C23) and the pyridine ring for 5 are stacked with mean planes angles between the rings of $4.015^{\circ}$ and $7.155^{\circ}$ respectively. The centroid to centroid distances of the stacked rings for $\mathbf{1}, \mathbf{3}$, and $\mathbf{5}$ are $3.699 \AA, 3.783 \AA$, and $3.882 \AA$ and the shift distances of centroids are $1.520 \AA, 1.345 \AA$, and $1.838 \AA$, respectively.

a)

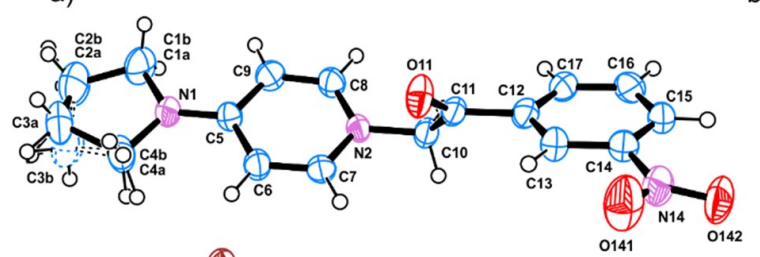

$(1) \mathrm{ar}$

c)

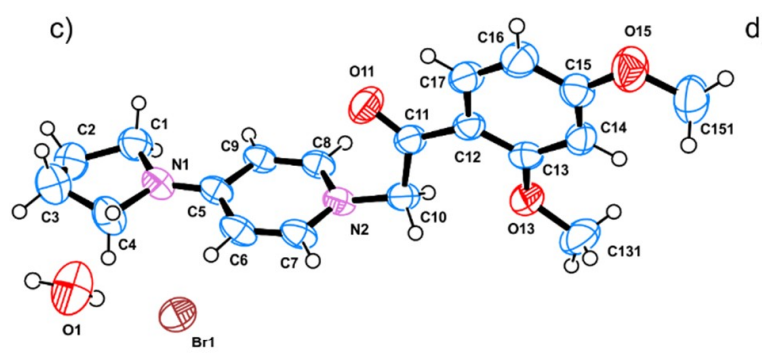

e)

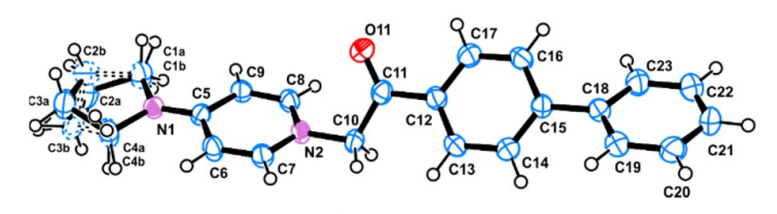

Bit b)

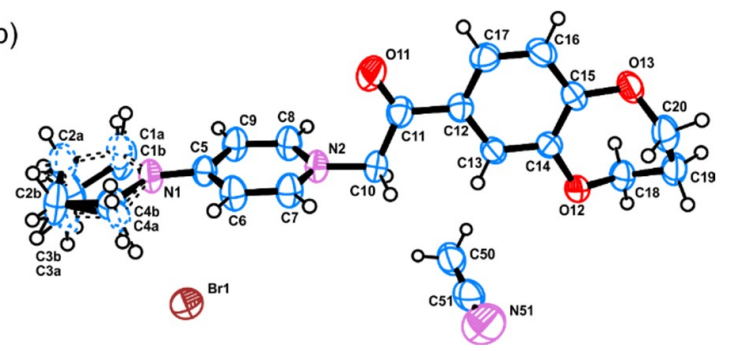

d)

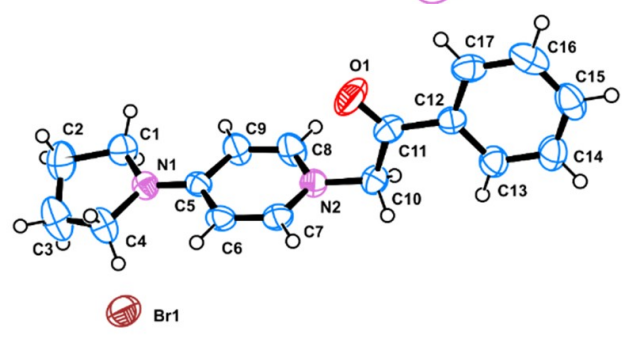

f)

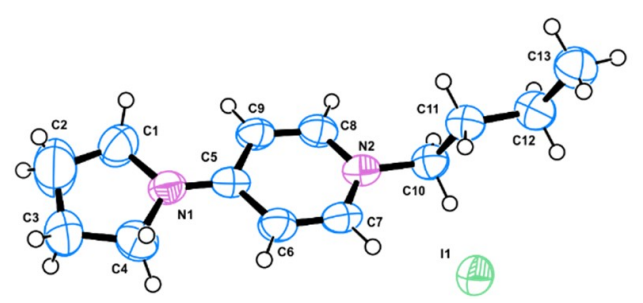

Figure 1. ORTEP [39] views of the molecules in the ASU of the crystal structures of (a) compound 1, (b) compound 2, (c) compound 3, (d) compound 4, (e) compound 5, and (f) compound 6. The thermal ellipsoids are drawn with $50 \%$ probability level and all atoms are given with an appropriate labeling scheme. 

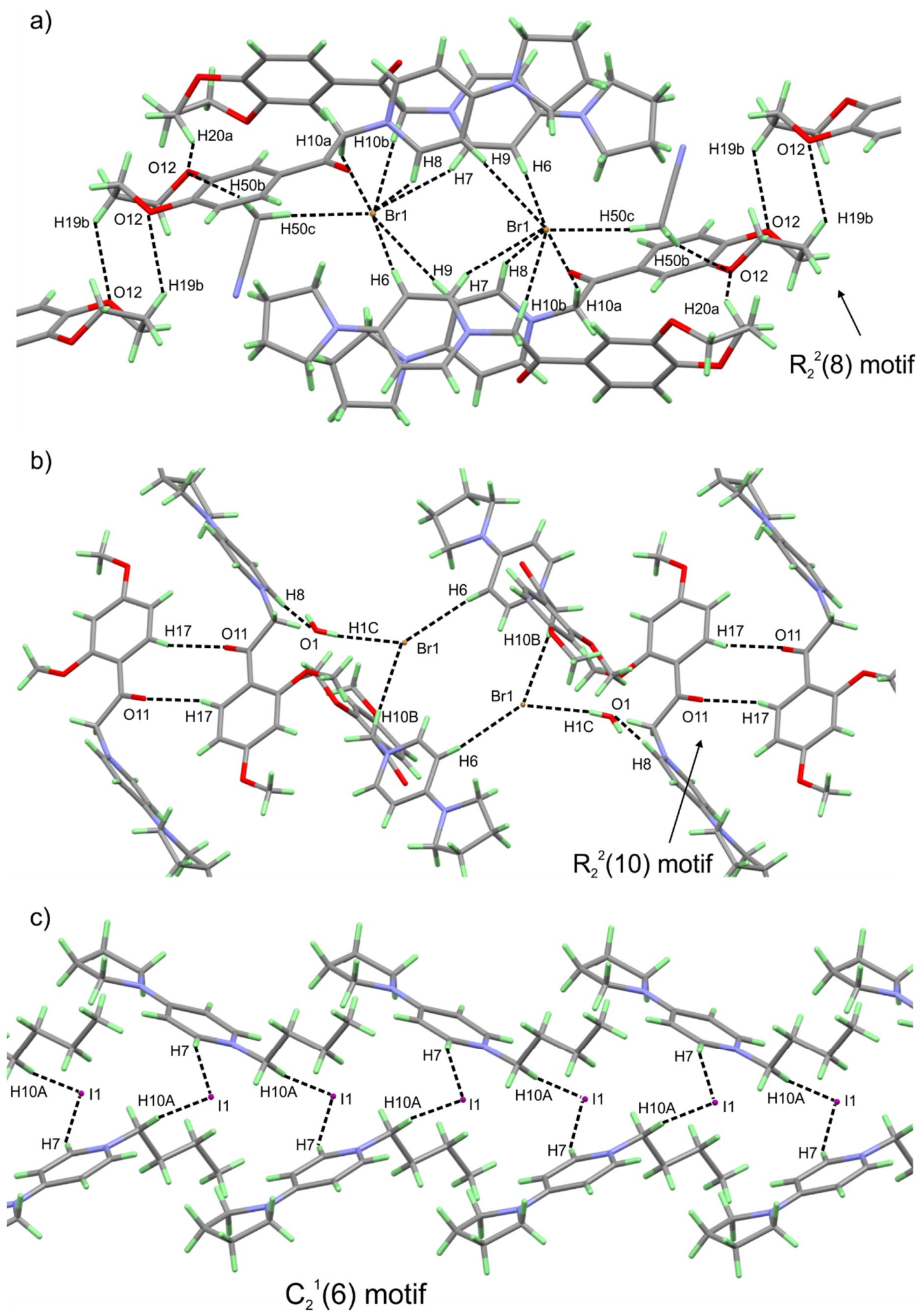

Figure 2. Halogen bonding interactions and short contacts for compounds $2-(\mathbf{a}), 3-(\mathbf{b})$ and $\mathbf{6}-(\mathbf{c})$. The three-dimensional packing of the molecules of 2,3 and 5 reveals specific pairing of the halogen bonding interactions between the QASs molecules, forming $\mathrm{R}_{2}{ }^{2}(8), \mathrm{R}_{2}{ }^{2}(10)$ and $\mathrm{C}_{2}{ }^{1}(6)$ motifs $[43,44]$, respectively. The hydrogen atoms are given in light green for better visualization. 


\subsection{DSC Studies}

The DSC data show that the crystal structure is conserved up to the melting point for compounds 1, 4, 5, and 6 (Figure 3 and Supplementary Materials). As mentioned, compounds 2 and 3 are crystal solvates and crystal hydrates with acetonitrile and water molecules present in the crystal structures. The DSC thermograms reveal that the water and acetonitrile molecules evaporate with broad endo effects covering the 67 to $97^{\circ} \mathrm{C}$ and 100 to $112^{\circ} \mathrm{C}$ temperature regions, respectively (Figure 3). The room temperature PXRD of compound 2 (Figure S2) showed a diffraction peak at $\sim 5.5^{\circ} 2 \theta$ that could not be related to the diffraction of the starting compounds or the generated pattern from single crystal data. Based on the DSC data we heated (e.g., dried) compound 2 for $1 \mathrm{~h}$ at $90{ }^{\circ} \mathrm{C}$ and collected PXRD again. The observed diffracting pattern was completely different from the initial one but replicated the peak at $5.5^{\circ} 2 \theta$. Thus, the peak at $5.5^{\circ} 2 \theta$ observed in the initial PXRD may be associated with the crystal phase without acetonitrile (most likely obtained during the grinding of the crystals). The PXRD results for 2 correlate well with the ${ }^{1} \mathrm{H}-\mathrm{NMR}$ studies which disclose only one molecular structure in solution and high purity of the compound. The melting points of 1-6 are spread in the $150-300{ }^{\circ} \mathrm{C}$ region. Interestingly, compounds 1-6 behave differently after they are melted. Some, such as 1, 3, 4 , and 5, start to decompose immediately or slightly after (interval of $10-15^{\circ} \mathrm{C}$ ) they melt while the decomposition of 2 and 6 occurs more than $120^{\circ} \mathrm{C}$ after the melting. The choice of a simple and cost-effective synthesis and purification procedures giving good yields and allowing the isolation of sufficiently pure compounds is supported by the DSC data revealing a sharp and narrow endo effects related to the melting points and confirmed by the NMR and PXRD data not showing traces of the starting organic compounds.

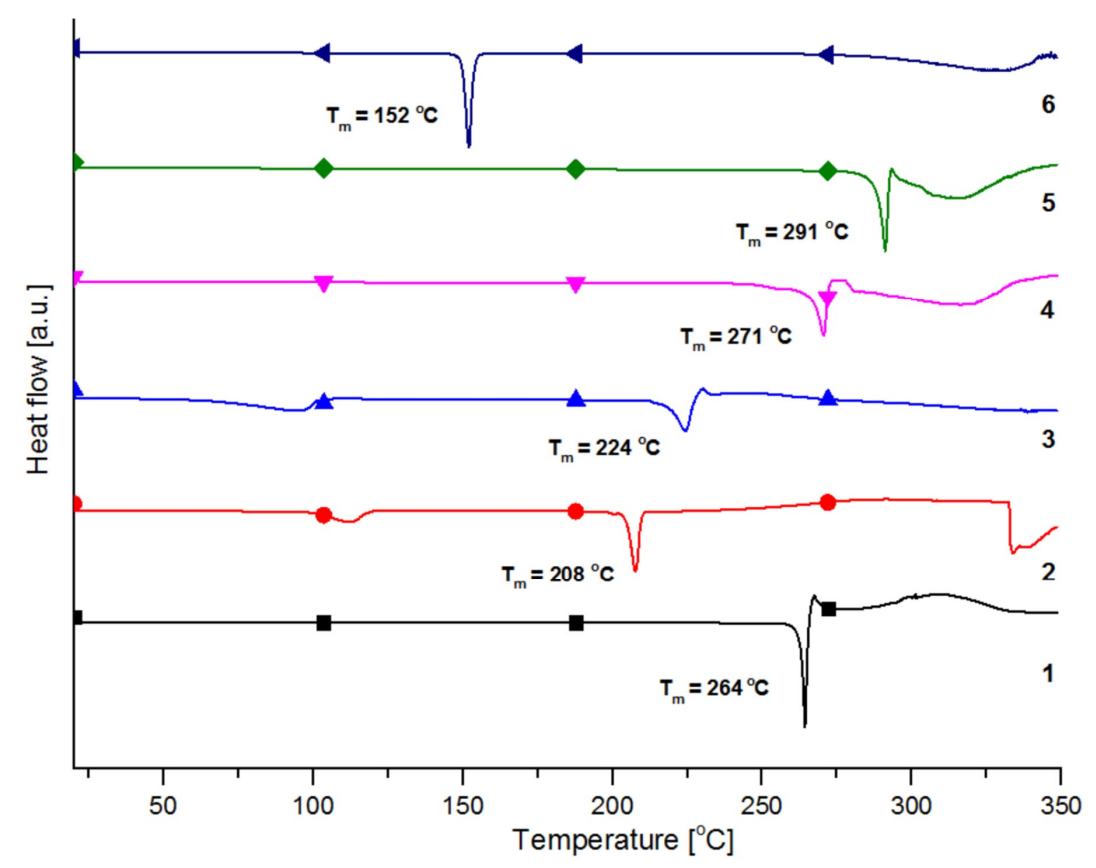

Figure 3. Combined graphical representation of the results from the DSC analyzes for compounds 1-6 with appropriate color and symbol scheme. The maxima of the endo effects, corresponding to the melting temperatures $\left(\mathrm{T}_{\mathrm{m}}\right)$ for all compounds, are denoted.

\subsection{Antibacterial Susceptibility Testing and Activity}

In our previous work [36] the antibacterial activity of 1-(2-(naphthalen-2-yl)-2-oxoethyl)-4-(pyrrolidin-1-yl) pyridin-1-ium bromide (CCDC 1875089) was checked against Klebsiella pneumoniae, Escherichia coli, Staphylococcus aureus and Bacillus subtilis and showed inhibitory activity only against $S$. aureus (inhibition zone of $16 \mathrm{~mm}$ ). Based on the exhibited specific activity, we decided to perform some additional random screening with different substituents 
to check if the activity is solely due to the 4-pyrrolidino pyridine moiety or is a combination between the different substituents.

Compounds 1-6 have been screened for antibacterial activities using disk diffusion method by measuring the inhibition zone in $\mathrm{mm}$. Kanamycin $(30 \mu \mathrm{g})$ was used as standard drug for antibacterial activity. The initial investigation of the antibacterial activity showed that only two of them, namely 3 and 5, exhibit comparatively good inhibitory effect against Escherichia coli and Staphylococcus aureus, respectively. Based on the screening the antibacterial experiments for 3 and 5 against $E$. coli and S. aureus, respectively, were performed three times with consistent antibacterial effect (Figure 4). The measured inhibition zone of $\mathbf{3}$ and $\mathbf{5}$ (given as average of several measurements, Table S4) are comparable to the kanamycin reference with values of $18 \mathrm{~mm}$ vs $21 \mathrm{~mm}$ and $14 \mathrm{~mm}$ vs $16 \mathrm{~mm}$, respectively. The factors controlling antimicrobial activity of the substituted pyridinium salts are the hydrophobicity, adsorbability, surface activity, position of the substituents and electron density of the ammonium nitrogen atom. In order to design novel effective antimicrobial agents, we need to understand the structure activity relation of the different factors. Here all six compounds have an identical 4-pyrrolidino pyridine moiety containing the quaternary nitrogen atom and thus the differences of the observed effects may be explained by the different substituent and the different hydrophobicity of the compounds. The $\log P$ values for compounds $1-6$ are $2.21( \pm 1.61), 2.37( \pm 1.78), 3.87( \pm 1.78)$, $2.14( \pm 2.1), 3.81( \pm 2.21)$, and $2.09( \pm 2.38)$, respectively [45]. Indeed, the values for compound 3 (as hydrate) and 5 differ from the remaining trend ( 2.2) suggestion an easier passage through the cell membrane. Interestingly the overlay of the molecules present in the ASU of $\mathbf{3}$ and $\mathbf{5}$ did not reveal drastic differences. The main variation occurs in the respective orientation of the 2,4-dimethoxyphenyl and 1,1'-biphenyl]-4-yl aromatic rings (Figure 5). The overlay of $\mathbf{3}$ with compounds 1, 2, $\mathbf{4}$, and $\mathbf{6}$ also discloses a highly conserved geometry of the 4-pyrrolidino pyridine moiety and small variation in the rotational orientation of the substituents. Thus, the bacterial specificity to E. coli and S. aureus should be explained by the different substituents: 2,4-dimethoxyphenyl and 1,1'-biphenyl]-4-yl. One should note that the specificity is not Gram-positive or Gram-negative related because compounds $\mathbf{3}$ and $\mathbf{5}$ are not inhibiting the growth of the other $\mathrm{G}^{+}$(Bacillus subtilis) and $\mathrm{G}^{-}$(Klebsiella pneumoniae subsp. ozaenae, Pseudomonas aeruginosa) bacteria in the test set. Thus, compounds $\mathbf{3}$ and $\mathbf{5}$ are suitable for targeting of a specific bacterial species.

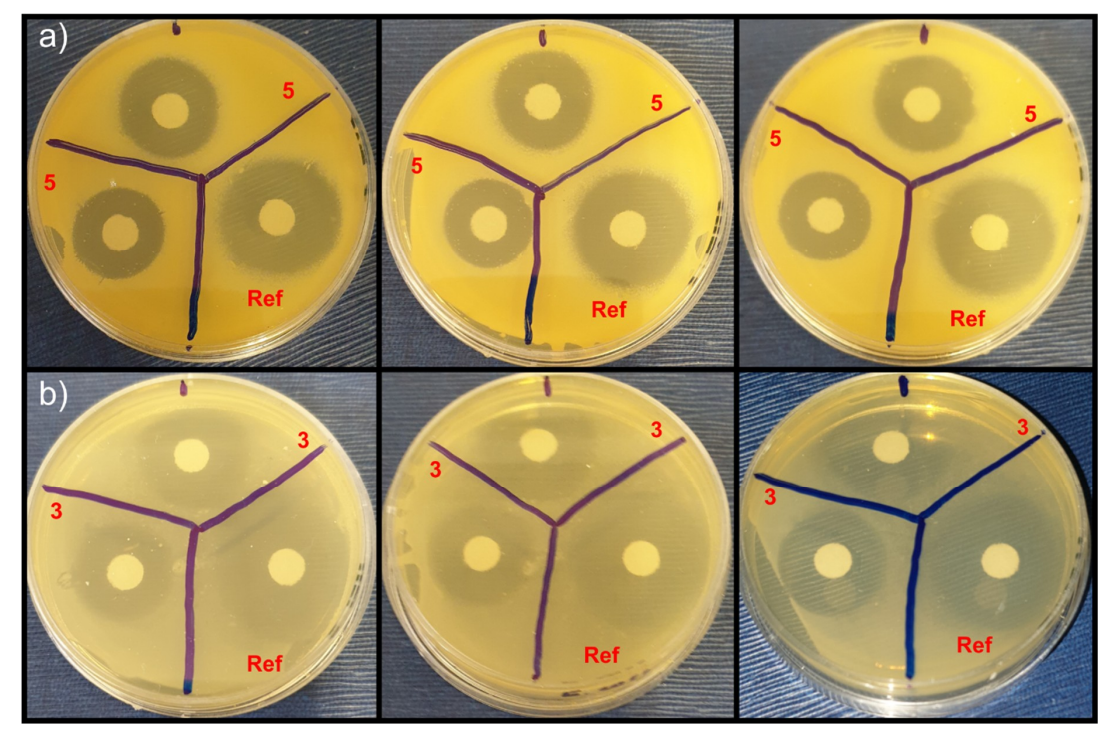

Figure 4. Observed antibacterial effect (experiments were repeated three times) corresponding to $30 \mu \mathrm{g}$ of compound 5 against $S$. aureus (a) and compound 3 against $E$. coli (b), compared to $30 \mu \mathrm{g}$ kanamycin (reference). The diameter of the area around the discs, containing the tested compounds, in which no visible growth is observed (zone of inhibition) was measured using ImageJ software [46]. 


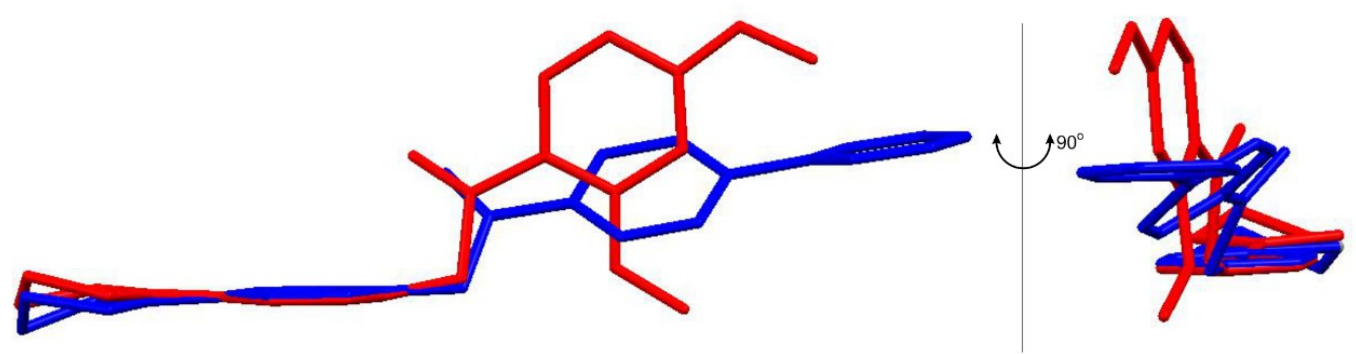

Figure 5. Overlay of the molecules present in the ASU of compounds $\mathbf{3}$ (red) and $\mathbf{5}$ (blue) in two orientations (rotated at $90^{\circ}$ ) showing the conserved geometry of the 4-pyrrolidino pyridine moiety and the rotational freedom around the $\mathrm{C} 11-\mathrm{C} 12$ bond; hydrogen atoms have been omitted for clarity.

\section{Conclusions}

We demonstrated a facile synthesis and purification procedure of quaternary ammonium derivatives of 4-pyrrolidino pyridine containing different aromatic substituents. In all cases, the purification of the compounds by simple washing with solvent and/or recrystallization (methanol, acetonitrile or methanol/acetone) produces reasonable yields (60-74\%). The compounds were screened for antimicrobial activity against Gram-positive and Gram-negative bacterial strains (five in total) and two of the compounds, 1-(2-(2,4-dimethoxyphenyl)-2-oxoethyl)-4-(pyrrolidin-1-yl)pyridin-1-ium bromide and 1-(2-([1,1'-biphenyl]-4-yl)-2-oxoethyl)-4-(pyrrolidin-1-yl) pyridin-1-ium bromide, showed inhibition activity similar or better than the kanamycin control. Single crystal analysis revealed that in all compounds, $\mathrm{H} \cdots \mathrm{X}$ halogen along with $\pi-\pi$ interactions, are responsible for the stabilization of the crystal structures. The 4-pyrrolidino pyridine moiety displays a highly conserved structural geometry and the observed differences in the antimicrobial activity arise from the different hydrophobicity while the specificity is due to the aromatic substituents. The results show that the observed activities are not solely linked to the 4-pyrrolidine-pyridinium fragment and that additional synthesis of various wisely designed compounds need to be undertaken.

Supplementary Materials: The following are available online at http://www.mdpi.com/2073-4352/10/5/339/s1; Figures S1, S3, S4, S5, and S6: Comparison of the Powder X-ray diffraction pattern (blue) versus Single Crystal X-ray diffraction pattern (generated via Mercury software, red) for compounds 1, 3, 4, 5, and 6, respectively; Figure S2: Powder X-ray diffraction patterns of compound 2 as crystallized at room temperature (blue) versus Single Crystal X-ray diffraction pattern (generated via Mercury software, red) for compound 2, starting compound 1 (green), starting compound 2 (yellow) and after heating at $90{ }^{\circ} \mathrm{C}$ (magenta); Figures S7, S8, S9, S10, S11, and S12: ${ }^{1} \mathrm{H}$ NMR spectra of compounds 1-6, respectively; Figures S13, S14, S15, S16, S17, and S18: ${ }^{1} \mathrm{H}-{ }^{1} \mathrm{H}$ NOESY spectra of compounds 1-6, respectively; Figure S19: ${ }^{1} \mathrm{H}-{ }^{1} \mathrm{H}$ COSY spectrum of compound 2; Figures S20, S21, S22, S23, S24, and S25: ${ }^{1} \mathrm{H}_{-}{ }^{13} \mathrm{C}$ HSQC spectrum of compounds 1-6, respectively; Figures S26, S27, S28, S29, S30, and S31: ${ }^{1} \mathrm{H}_{-}{ }^{13} \mathrm{C}$ HMBC spectrum of compounds 1-6, respectively; Figures S32, S33, and S34: ${ }^{13} \mathrm{C}$ NMR spectrum of compounds 4-6, respectively; Figures S35, S36, S37, S38, S39, and S40: Observed thermal effects from the DSC analysis of compounds 1-6, respectively; Figure S41: Observed low antibacterial effect for compounds 1-6 against $P$. Aeruginosa-a, K. Pneumoniae- b, and B. subtilis-c, compared to kanamycin reference; Figure S42: Observed antibacterial effect for compounds 1-6 against $E$. coli-a, and $S$. aureus - $\mathbf{b}$ compared to kanamycin reference; Table S1. The most important parameters from the SCXRD experiment of compounds 1-6, Table S2: Selected bond lengths and angles determined from the SCXRD experiment of compounds 1-6, Table S3: Halogen bonding interactions and short contacts for the crystal structures of 1-6. Table S4: Measured inhibition zone for compounds 3 and 5 against E. coli and S. aureus.

Author Contributions: Conceptualization, R.R. and B.S.; methodology, B.S.; investigation, R.R. and B.S.; writing-original draft preparation, R.R. and B.S..; writing—review and editing V.K.; visualization, R.R. and B.S.; supervision B.S. and V.K.; project administration, B.S. All authors have read and agreed to the published version of the manuscript.

Funding: This research was partially supported by the Bulgarian ministry of education and science under the national research programme "Young scientists and postdoctoral students" approved by dcm \# 577 / 17.08.2018 and NFNI grant T02/14". 
Acknowledgments: The authors acknowledge the technical support from the project PERIMED BG05M2OP001-1.002-0005 /29.03.2018 (2018-2023) and B.S. the financial support of K2-2020 of IMC-BAS.

Conflicts of Interest: The authors declare no conflict of interest.

\section{References}

1. Garcia, M.T.; Kaczerewska, O.; Ribosa, I.; Brycki, B.; Materna, P.; Drgas, M. Biodegradability and aquatic toxicity of quaternary ammonium-based gemini surfactants: Effect of the spacer on their ecological properties. Chemosphere 2016, 154, 155-160. [CrossRef] [PubMed]

2. Shukla, D.; Tyagi, V. Cationic gemini surfactants: A review. J. Oleo Sci. 2006, 55, 381-390. [CrossRef]

3. Liu, S.; Kumatabara, Y.; Shirakawa, S. Chiral quaternary phosphonium salts as phase-transfer catalysts for environmentally benign asymmetric transformations. Green Chem. 2016, 18, 331-341. [CrossRef]

4. Kaneko, S.; Kumatabara, Y.; Shirakawa, S. A new generation of chiral phase-transfer catalysts. Org. Biomol. Chem. 2016, 14, 5367-5376. [CrossRef]

5. Mondal, M.G.; Pratap, A.P. Synthesis and properties of esterquats as antibacterial agent and fabric softener. Tenside Surfactants Deterg. 2017, 54, 78-84. [CrossRef]

6. Tawfik, S.M. Ionic liquids based gemini cationic surfactants as corrosion inhibitors for carbon steel in hydrochloric acid solution. J. Mol. Liq. 2016, 216, 624-635. [CrossRef]

7. Marino, M.; Kreuer, K. Alkaline stability of quaternary ammonium cations for alkaline fuel cell membranes and ionic liquids. ChemSusChem 2015, 8, 513-523. [CrossRef]

8. Liao, J.; Ye, Z. Quaternary ammonium cationic polymer as a superior bifunctional binder for lithium-sulfur batteries and effects of counter anion. Electrochim. Acta 2018, 259, 626-636. [CrossRef]

9. Kwok, C.Y.; Pang, Q.; Worku, A.F.; Liang, X.; Gauthier, M.; Nazar, L.F. Impact of the mechanical properties of a functionalized cross-linked binder on the longevity of Li-S batteries. Acs Appl. Mater. Interfaces 2019, 11, 22481-22491. [CrossRef]

10. Tenover, F.C. Mechanisms of antimicrobial resistance in bacteria. Am. J. Med. 2006, 119, S3-S10. [CrossRef]

11. Tischer, M.; Pradel, G.; Ohlsen, K.; Holzgrabe, U. Quaternary ammonium salts and their antimicrobial potential: Targets or nonspecific interactions? ChemMedChem 2012, 7, 22-31. [CrossRef]

12. Dunning Hotopp, J.C. Horizontal gene transfer between bacteria and animals. Trends Genet. (Regul. Ed.) 2011, 27, 157-163. [CrossRef] [PubMed]

13. Livermore, D.M. Bacterial resistance: Origins, epidemiology, and impact. Clin. Infect. Dis. 2003, 36, S11-S23. [CrossRef] [PubMed]

14. Schindler, B.D.; Kaatz, G.W. Multidrug efflux pumps of gram-positive bacteria. Drug Resist. Updates 2016, 27, 1-13. [CrossRef] [PubMed]

15. Worthington, R.J.; Melander, C. Overcoming resistance to $\beta$-lactam antibiotics. J. Org. Chem. 2013, 78, 4207-4213. [CrossRef]

16. Buffet-Bataillon, S.; Tattevin, P.; Maillard, J.-Y.; Bonnaure-Mallet, M.; Jolivet-Gougeon, A. Efflux pump induction by quaternary ammonium compounds and fluoroquinolone resistance in bacteria. Future Microbiol. 2016, 11, 81-92. [CrossRef]

17. Locher, H.H.; Ritz, D.; Pfaff, P.; Gaertner, M.; Knezevic, A.; Sabato, D.; Schroeder, S.; Barbaras, D.; Gademann, K. Dimers of nostocarboline with potent antibacterial activity. Chemotherapy 2010, 56, 318-324. [CrossRef]

18. Tischer, M.; Sologub, L.; Pradel, G.; Holzgrabe, U. The bisnaphthalimides as new active lead compounds against plasmodium falciparum. Bioorganic Med. Chem. 2010, 18, 2998-3003. [CrossRef]

19. Ma, M.; Sun, G. Antimicrobial cationic dyes: Part 2-Thermal and hydrolytic stability. Dye. Pigment. 2004, 63, 39-49. [CrossRef]

20. Kang, C.K.; Kim, S.S.; Kim, S.; Lee, J.; Lee, J.-H.; Roh, C.; Lee, J. Antibacterial cotton fibers treated with silver nanoparticles and quaternary ammonium salts. Carbohydr. Polym. 2016, 151, 1012-1018. [CrossRef]

21. Liu, G.; Wu, G.; Jin, C.; Kong, Z. Preparation and antimicrobial activity of terpene-based polyurethane coatings with carbamate group-containing quaternary ammonium salts. Prog. Org. Coat. 2015, 80, 150-155. [CrossRef]

22. Tan, W.; Li, Q.; Dong, F.; Wei, L.; Guo, Z. Synthesis, characterization, and antifungal property of chitosan ammonium salts with halogens. Int. J. Biol. Macromol. 2016, 92, 293-298. [CrossRef] [PubMed] 
23. Wei, L.; Li, Q.; Chen, Y.; Zhang, J.; Mi, Y.; Dong, F.; Lei, C.; Guo, Z. Enhanced antioxidant and antifungal activity of chitosan derivatives bearing 6-o-imidazole-based quaternary ammonium salts. Carbohydr. Polym. 2019, 206, 493-503. [CrossRef] [PubMed]

24. Zhang, A.; Liu, Q.; Lei, Y.; Hong, S.; Lin, Y. Synthesis and antimicrobial activities of acrylamide polymers containing quaternary ammonium salts on bacteria and phytopathogenic fungi. React. Funct. Polym. 2015, 88, 39-46. [CrossRef]

25. Conejo-García, A.; Pisani, L.; del Carmen Núnez, M.; Catto, M.; Nicolotti, O.; Leonetti, F.; Campos, J.M.; Gallo, M.A.; Espinosa, A.; Carotti, A. Homodimeric bis-quaternary heterocyclic ammonium salts as potent acetyl-and butyrylcholinesterase inhibitors: A systematic investigation of the influence of linker and cationic heads over affinity and selectivity. J. Med. Chem. 2011, 54, 2627-2645. [CrossRef]

26. Obligacion, J.V.; Chirik, P.J. Bis (imino) pyridine cobalt-catalyzed alkene isomerization-hydroboration: A strategy for remote hydrofunctionalization with terminal selectivity. J. Am. Chem. Soc. 2013, 135, 19107-19110. [CrossRef]

27. Dalaigh, C.O.; Hynes, S.J.; O’Brien, J.E.; McCabe, T.; Maher, D.J.; Watson, G.W.; Connon, S.J. Asymmetric acyl-transfer promoted by readily assembled chiral 4-n, n-dialkylaminopyridine derivatives. Org. Biomol. Chem. 2006, 4, 2785-2793. [CrossRef]

28. Uchida, N.; Kuwabara, J.; Taketoshi, A.; Kanbara, T. Molecular design of organic superbases, azacalix [3](2, 6) pyridines: Catalysts for 1, 2-and 1, 4-additions. J. Org. Chem. 2012, 77, 10631-10637. [CrossRef]

29. Małecki, J.G.; Maron, A. Chloride and pseudohalide hydride-carbonyl ruthenium (ii) complexes with 4-pyrrolidinopyridine as co-ligand. Transit. Met. Chem. 2013, 38, 133-142. [CrossRef]

30. Abboud, J.-L.M.; Notario, R.; Bertrán, J.; Solà, M. One century of physical organic chemistry: The Menshutkin reaction. Prog. Phys. Org. Chem. 1993, 19, 1-182.

31. Sola, M.; Lledos, A.; Duran, M.; Bertran, J.; Abboud, J.L.M. Analysis of solvent effects on the menshutkin reaction. J. Am. Chem. Soc. 1991, 113, 2873-2879. [CrossRef]

32. Castejon, H.; Wiberg, K.B. Solvent effects on methyl transfer reactions. 1. The menshutkin reaction. J. Am. Chem. Soc. 1999, 121, 2139-2146. [CrossRef]

33. Acevedo, O.; Jorgensen, W.L. Exploring solvent effects upon the menshutkin reaction using a polarizable force field. J. Phys. Chem. B 2010, 114, 8425-8430. [CrossRef] [PubMed]

34. Ropponen, J.; Lahtinen, M.; Busi, S.; Nissinen, M.; Kolehmainen, E.; Rissanen, K. Novel one-pot synthesis of quaternary ammonium halides: New route to ionic liquids. New J. Chem. 2004, 28, 1426-1430. [CrossRef]

35. Campos, J.N.; del Carmen Núñez, M.A.; Rodríguez, V.; Entrena, A.; Hernández-Alcoceba, R.; Fernández, F.; Lacal, J.C.; Gallo, M.A.; Espinosa, A. Lumo energy of model compounds of bispyridinium compounds as an index for the inhibition of choline kinase. Eur. J. Med. Chem. 2001, 36, 215-225. [CrossRef]

36. Rusew, R.; Kurteva, V.; Shivachev, B. Antibacterial activity of novel quaternary ammonium salts of quinoline and 4-pyrolidino pyridine. Bulg. Chem. Commun. 2018, 50F, 115-125.

37. Rigaku, O. Crysalis pro; Rigaku Oxford Diffraction: Yarnton, UK, 2015.

38. Sheldrick, G.M. A short history of shelx. Acta Crystallogr. Sect. A: Found. Crystallogr. 2008, 64, $112-122$.

39. Farrugia, L.J. Ortep-3 for windows-a version of ortep-III with a graphical user interface (GUI). J. Appl. Crystallogr. 1997, 30, 565. [CrossRef]

40. Schmidt, A.; Mordhorst, T.; Nieger, M. From uncharged to decacationic molecules: Syntheses and spectroscopic properties of heteroarenium-substituted pyridines. Org. Biomol. Chem. 2005, 3, 3788-3793. [CrossRef]

41. Schmidt, A.; Vainiotalo, P.; Kindermann, M.K.; Nieger, M. Synthesis, esi and fab mass spectrometry, and $\mathrm{x}$-ray analysis of di-and tricationic pyridinium substituted pyrimidines. Heterocycles 2002, 57, 615-621.

42. Sasaki, I.; Daran, J.-C.; Commenges, G. The simple production of nonsymmetric quaterpyridines through kröhnke pyridine synthesis. Beilstein J. Org. Chem. 2015, 11, 1781-1785. [CrossRef] [PubMed]

43. Grell, J.; Bernstein, J.; Tinhofer, G. Graph-set analysis of hydrogen-bond patterns: Some mathematical concepts. Acta Crystallogr. Sect. B Struct. Sci. 1999, 55, 1030-1043. [CrossRef]

44. Bernstein, J.; Davis, R.E.; Shimoni, L.; Chang, N.L. Patterns in hydrogen bonding: Functionality and graph set analysis in crystals. Angew. Chem. Int. Ed. Engl. 1995, 34, 1555-1573. [CrossRef] 
45. Tetko, I.V.; Gasteiger, J.; Todeschini, R.; Mauri, A.; Livingstone, D.; Ertl, P.; Palyulin, V.A.; Radchenko, E.V.; Zefirov, N.S.; Makarenko, A.S.; et al. Virtual computational chemistry laboratory-design and description. J. Comput.-Aided Mol. Des. 2005, 19, 453-463. [CrossRef] [PubMed]

46. Rueden, C.T.; Schindelin, J.; Hiner, M.C.; DeZonia, B.E.; Walter, A.E.; Arena, E.T.; Eliceiri, K.W. Imagej2: Imagej for the next generation of scientific image data. Bmc Bioinform. 2017, 18, 1-26. [CrossRef] [PubMed] 